\title{
PEMIKIRAN MISTIKO-FILOSOFIS MULYADHI KARTANEGARA
}

\author{
Matroni \\ Sekolah Tinggi Keguruan dan Ilmu Pendidikan, Sumenep, Indonesia \\ matroni@stkippgrisumenep.ac.id
}

\begin{abstract}
Mulyadhi Kartanegara is an Indonesian thinker has offered Islamic epistemology called as mystico-philosophic. What is Mulyadhi's concept of Mysticophilosophic? What is it's implication on development of contemporary metaphysics? It is library-based philosophical research that is studying data and references which are relevant with subject, including papers, books, newspapers, journals, and interviews. The results were firstly that mystico-philosophic offers new paradigm in Islamic philosophy. The second one, that it offers synthesis between religion and philosophy or sufism and philosophy. The third one, that it enables the synergy among rationality, senses and intuition. Those three components must be fulfilled in that epistemology. The fourth one, that is that senses, rationality and intuition are islamic epistemological foundations must be defended. The fifth one, that islamic epistemology tends to transcend daily life in order those three components keep synergy. The sixth, mystico-philosophic truly is needed in our contemporary century.
\end{abstract}

Keywords: Islamic Philosophy, Islamic Mysticism, Sufism

Abstrak. Mulyadhi Kartanegara adalah salah satu pemikir Indonesia yang mencoba berjuang menawarkan epistemologi Islam yang dikenal dengan mistiko-filosofis. Masalah utamanya adalah, apa dan bagaimana pemikiran Mulyadi Kartanegara tentang Mistiko-Filosofis; dan Bagaimana implikasinya terhadap perkembangan metafisika kontemporer? Penelitian ini berbasis pustaka dengan mengumpulkan data, sekaligus meneliti referensi-referensi yang terkait dengan subjek yang dikaji, baik makalah, buku, Koran, jurnal, peper sekaligus wawancara dengan menggunakan pendekatan filosofis. Hasilnya adalah, bahwa mistiko-filosofis mampu memberikan paradigma baru dalam filsafat Islam. Kedua mampu memberikan penyadaran dalam mendamaikan agama dan filsafat, tasawuf dan filsafat. Ketiga dalam mistiko-filosofis peran akal, indera dan hati sama-sama harus berjalan bermesraan, artinya belum dikatakan mistiko-filosofis kalau dalam filsafat Islam tidak menyertakan akal, indera dan hati. Keempat indera, akal, dan hati merupakan fondasi epistemologi Islam yang harus tetap dijaga dan dilestarikan. Kelima ada semangat untuk mendransendenkan atau memistikkan keseharian agar tiga fondasi ini tidak bersebrangan dan tidak berdiri sendiri. Keenam ternyata mistikofilosofis benar-benar dibutuhkan oleh abad komtemporer.

Kata Kunci: Filsafat Islam, Mistisisme Islam, Tasawuf 


\section{Pendahuluan}

Dalam dunia pengetahun, mistik selalu dicurigai, hal ini wajar, mengingat pemikiran mistik berada pada ekstrem yang berseberangan dengan pemikiran rasional yang memang sudah menjadi basis metode saintifik. ${ }^{1}$ Mistisisisme kadang dicampuradukan dengan dukun, dan paranormal.

Sebenarnya banyak para pemikir dunia seperti Eintein, Pauli, Schrodinger, Heisenberg, Eddington, dan Jeans yang mendukung adanya mistisisme. ${ }^{2}$ Sebab esensi pengalaman mistik merupakan sejenis jalan pintas menuju kebenaran, kontak langsung dan tanpa mediasi dengan suatu realitas tertinggi yang dipersepsikan.

Pengakuan tokoh ini sebenarnya ingin membuktikan bahwa mistik juga memiliki peranan penting dalam memberikan sumbangsih pemikiran dan pengetahuan, namun pengakuan ini terjadi setelah mengalami pergulatan yang luar biasa membabat habis jiwajiwa dunia Barat dari kepungan akal atau rasio.

Filsafat (al-Hikmah, falsafah) Islam sejak lahir 1.200 tahun yang lalu, hingga sekarang merupakan salah satu tradisi intelektual besar di dalam dunia Islam yang mampu mempengaruhi dan dipengaruhi banyak perspektif intelektual lain, termasuk teologi skolastik (kalam) dan sufisme dokrinal (al-ma'rifah, irfani). ${ }^{3}$

Ada empat pokok yang di bahas dalam tradisi intelektual Islam yaitu Tuhan, alam, jiwa, manusia dan hubungan antar pribadi4. Tiga unsur

1 Paul Davies, Membaca Pikiran Tuhan, Dasar-Dasar Ilmiah dalam Dunia yang Rasional, terj. Hamzah, (Yogyakarta: Pustaka Pelajar, 2012), h. 381.

2 Ibid., Paul Davies, Membaca Pikiran..., h. 381.

3 Sayyed Hossien Nasr, "Filsafat" dalam Ensiklopedi Oxpord, Dunia Islam Modern, diedit oleh John L Esposito, (Bandung: Mizan, 2002), jilid 2: h. 71. inilah yang membentuk realitas manusia, karena manusia memiliki kemampuan membaca dari sumbersumber pengetahuan yang ada dalam alQur'an dan Hadist.

Wajar jika kemudian apa yang ada dalam pemikiran-pemikiran abad modern jarang sejalan dengan pembelajaran Islam adalah dengan merefleksikan lahirnya modernitas dengan berbagai pola pikir dan normanorma "kebudayaan global"5 yang di dalamnya manusia hidup bersama, saling memberikan pemikiran dan saling berwacana, walau pun semakin jauh dari Tuhan.

Wajar kemudian jika para filsuf Muslim umumnya membahas mengenai banyak hal, sehingga terkesan campuraduk. Membaca karya-karya asli filsuf Islam akan memusingkan karena seringkali tidak terstruktur rapi melainkan seperti fragmen atau percikan pemikiran belaka. Bahkan dalam metode tasawuf, banyak yang menuliskan soal mimpi yang dialami dan kemudian menyusun tafsir ( $\left.t a^{\prime} w i l\right)$-nya.

Beberapa filsuf juga menuliskan karyanya dalam bentuk karya sastra seperti novel, prosa bahkan puisi, yang membuatnya makin sulit dimengerti. Ini karena berbeda dengan filsuf Barat, filsuf Muslim banyak yang terilhami oleh Tuhan dengan cara yang luar biasa, termasuk lewat mimpi. Karena itu terkadang tulisannya pun menjadi penuh penyingkapan gaib (kasyaf) ${ }^{6}$

Tulisan para filsuf Islam bisa jadi luas, namun tetap ada fokus dari tiap filsuf. Kecenderungannya adalah filsuf

4 William C. Chittik, Kosmologi Islam dan Dunia Modern, terj. Arif Mulyadi, (Jakarta: Mizan Publika, 2010), h. 2.

${ }^{5}$ Ibid., William C. Chittik, Kosmologi Islam..., h. 16 .

6 Bhayu, "Filsafat Islam: Pembagian Skema Sejarah",

http://lifeschool.wordpress.com/2011/03/04 /filsafat-islam-3-pembagian-skema-sejarah/, diakses tanggal 8 Desember 2012, jam 22. 
yang kemudian biasanya mengkritisi filsuf terdahulu, sehingga akan muncul disiplin atau cara pandang baru. Dari sinilah kemudian munculah nama-nama filsuf Islam besar yang menjadi pelopor aliran masing-masing, misalnya Suhrawardi yang menjadi "bapak iluminisme" atau al-Ghazali yang fokus pada masalah teologi dan mistisisme dan Muhammad Iqbal yang terjun di dunia sastra, filsafat dan mistik.

Filsafat sebagai pengetahuan yang berkaitan dengan bentuk-bentuk kehidupan $^{7}$ dimana dalam kehidupan, manusia selalu dituntut untuk percaya kepada yang gaib yaitu Tuhan, dari sinilah ada indikasi bahwa filsafat secara umum dan salah satu cabangnya yaitu epistemologi ${ }^{8}$ (theory of knowledge) dalam perkembangannya senantiasa mengalami perubahan dalam konteks sejarah dan pergeserannya, baik ditinjau dari sisi teoritis maupun dari sisi praktis, yang tidak bisa dilepaskan dari peran manusia dalam kondratnya sebagai pencari pengetahuan atau sebagai penafsir realitas.

7 F. Budi Hardiman, Filsafat Modern dari Machiavelli sampai Nietzsche (Jakarta: Gramedia Pustaka Utama, 2004), h. 1.

8 Term epistemologi secara etemologi berasal dari kata Yunani: epescmc $=$ knowledge, pengetahuan $+\operatorname{logos}=$ teori. Istilah ini pertama kali digunakan pada tahun 1854 oleh J.F Ferrier yang membuat perbedaan antara dua cabang filsafat yaitu ontologi (Yunani: on = Being, wujud, apa + logos = teori) dan epistemologi. Ontologi sering disinonimkan dengan metafisika, meskipun yang disebutkan terakhir ini berarti dapat berarti ontologi yang merupakan teori tentang apa, juga berarti pula epistemologi sebagai teori ilmu pengetahuan. (Lihat. Milton D. Hunnex, Peta Filsafat, Pendekatan Kronologis dan Tematis, terj. Zubair (Bandung: Teraju, 2004), hal. 7-8). Dan dapat dilihat juga dalam. Loren Bagus, Kamus Filsafat (Jakarta: Gramedia Pustaka Utama, 2000), h. 212.

Sementara secara terminologi, terdapat berbagai corak definisi, namun pada dasarnya sama, yakni mengacu pada ilmu pengetahuan (theory of knowledge), di antaranya menurut
Di zaman modern dan pemikiran modern telah mengalami kehilangan satu pusat, satu orientasi, satu tujuan, satu sasaran untuk mencapai satu kebahagiaan dan satu kedamaian spiritual yang bernama mistik. Tidak ada satu "Tuhan", namun banyak Tuhan yang diciptakan oleh manusia itu sendiri yaitu berhala-berhala modernitas seperti materialisme, hedonisme, dan kapitalisme, yang mengakibatkan menyebarnya zaman modern yang berorientasi pada rasio dan materi, di saat itulah manusia mengalami krisis spiritual yang berkepanjangan.

Proses pergulatan manusia yang serba instan, dan menjalani proses tafsir yang terus-menerus, maka tuhan-tuhan tersebut berlipat ganda, sehingga melampaui hitungan, maka wajar ketika manusia memuja tuhan-tuhan mana saja yang menurut mereka menarik hati ${ }^{9}$ dan indah, wajar kemudian jika Tuhan merupakan sebuah produk imajinasi

filsuf besar Yunani kuno Aristoteles, epesteme adalah "an organized body of rational knowledge with its proper object" (suatu kumpulan yang teratur dalam pengetahuan rasional dengan objeknya sendiri yang tepat). Lihat juga. The Liang Gie, Pengantar Filsafat Ilmu (Yogyakarta: Liberty, 2000), halaman. 1. Menurut Jujun S. Suriasumantri epistemologi atau teori pengetahuan, membahas secara mendalam segenap proses yang terlihat dari usaha kita untuk memperoleh pengetahuan. Lihat juga, Jujun S. Suriasumantri Ilmu dalam Perspektif: Sebuah Kumpulan Karangan Tentang Hakikat Ilmu (Jakarta: Yayasan Obor Indonesia, 1997), halaman. 9. Menurut Musa Asy'Arie epistemologi merupakan cabang filsafat yang membicarakan mengenai hakikat ilmu, dan ilmu sebagai proses adalah usaha pemikiran yang sistematik dan metodik untuk menemukan prinsip kebenaran yang terdapat pada suatu objek kajian ilmu. Lihat Menurut Musa Asy'Arie Filsafat Islam, Sunna Nabi dalam Berfikir (Yogyakarta: LESFI, 2002), h. 63.

${ }^{9}$ Ibid., William C. Chittik, Kosmologi Islam..., h. 17 . 
kreatif, seperti halnya seni dan musik yang sangat inspiratif. ${ }^{10}$

Oleh karena itu, epistemologi Islam menghadapi krisis "pembacaan" yang mendalam dewasa ini. Umat Islam ${ }^{11}$ telah dilanda berbagai persoalah ilmiah filosofis $^{12}$, yang datang dari pandangan ilmiah-filosofis Barat yang bersifat sekuler. Berbagai teori ilmiah, dari berbagai bidang, fisika, biologi, psikologi, antropologi dan sosiologi, atas nama metode ilmiah atau otoritas ilmiah, menyerang fondasi-fondasi kepercayaan agama Islam. Seperti surat Galileo pada Lastelli pada tahun 1613 bahwa:

Menurutku dalam diskusi persoalan fisika kami tidak harus memulainya dari otoritas pernyataan kitab suci, tapi dari pengalaman indera dan demontrasi yang penting. Karena kitab Injil dan fenomena alam berlangsung sesuai prosedur dari kalam Tuhan karena alasan itu kelihatan bahwa tidak ada fisika yang ditunjukkan melalui pengalaman indera kepada kami, atau yang dibuktikan kepada kami melalui demontrasi penting yang harus

10 Karen Armstrong, Sejarah Tuhan, Kisah 4.000 Tahun Pencarian Tuhan dalam AgamaAgama Manusia, (Bandung: Mizan Pustaka, 2013), h. 21.

11 D.Z. Baneth "Apakah yang Dimaksud Muhammad Saw dengan Menamakan Agamanya "Islam"? dalam N.J.G. Kaptein (ed.), Sukarsi (penerj), Pandangan Barat Terhadap Islam Lama, (Jakarta: INIS, Jilid 4, 1989), h. 4-5. Islam dalam hal ini bukanlah merujuk pada kata verbal Islam yang di dalam Qur'an muncul agak belakangan, akan tetapi kata kerja aslama yang menunjuk pada suatu tindakan. Sebab jika kita sekarang mengumpulkan hasil-hasil kita untuk disimpulkan dan berusaha menemukan apa yang lazim untuk berbagai kata yang terbentuk dari akar salama tampaklah bahwa ide umumnya ialah tentang keseluruhan, keseluruhan atau totalitas, ide kesempurnaan yang sama ada di balik kata-kata itu, manakalah kita jumpai dalam pengertian penyerahan atau ketundukan mutlak, jadi Islam di sini lebih mempersoalkan (sedikit banyak disalahkan) kesaksian dalam al-kitab yang mungkin memiliki beberapa perbedaan makna di balik katakatanya, karena Injil tidak mengaitkan setiap ekspresi dengan kondisinya yang sama kakunya dengan kondisi yang mengatur semua efek fisika: Tuhan tidak diinginkan secara agak baik dalam peristiwa alam dibandingkan dalam pernyataan suci di dalam Injil. ${ }^{13}$

Tuhan tidak dipandang perlu lagi dibawa-bawa dalam penjelasan ilmiah. Seperti bagi Laplace ${ }^{14}$ (w. 1827), kehadiran Tuhan dalam pandangan ilmiah hanyalah menempati posisi hipotesa. Laplace mengatakan, sekarang saintis tidak memerlukan lagi hipotesa tersebut, karena alam telah bisa dijelaskan secara ilmiah tanpa harus merujuk kepada Tuhan.

Baginya, bukan Tuhan yang telah bertanggung jawab atas keteraturan alam, tetapi adalah hukum alam itu sendiri. Jadi Tuhan telah diberhentikan sebagai pemelihara dan pengatur alam. ${ }^{15}$

ditekankan pada kemutlakannya bukan pada ketundukan, begitupun dalam dunia tasawuf.

12 Mulyadhi Kartanegara, Menembus Batas Waktu, Panorama Filsafat Islam, (Bandung: Mizan, 2005), h. xxi.

13 Ian G Barbour, "Isu dalam Sains dan Agama”, terj. Damayati, (Yogyakarta: UIN Sunan Kalijaga, 2006), h. 40.

${ }^{14}$ Lebih jelasnya lihat, Agus Purwadianto. et al. Jalan Paradoks, Visi Baru Fritjof Capra tentang Kearifan dan Kehidupan Modern, (Jakarta: Teraju, 2004), h. 150. Lihat juga Ian G Barbour, Isu dalam Sain dan Agama, terj. Damayati (Yogyakarta: UIN Sunan Kalijaga, 2006), h. 58.

15 Mulyadhi Kartanegara, "Masa Depan Filsafat Islam: Antara Cita Dan Fakta", Paper yang disajikan pada acara Ulang tahun Paramadina yang ke XX, di Jakarta: pada tanggal 23 November 2006. Baca juga Zidi Gazalba, Sistematika Filsafat, Buku Pertama, Pengantar Kepada Filsafat, (Jakarta: Bulan Bintang, 1992), h. Xi. Lihat juga Bernard Lewis, Kemelut 
Menggunakan pisau analisis epistemologi Islam yang dalam hal ini mistik-filosofis, peneliti mencoba menjawab tantangan tersebut dan epistemologi sebagai cabang filsafat tentu memiliki makna filosofis yang perlu untuk dikaji dan ditelaah lebih dalam. Akan tetapi, epistemologi Islam belum mencapai tingkat kajian yang memadai di negeri ini, ${ }^{16}$ walau pun ada buku yang membahas tentang epistemologi, umumnya masih berupa kajian pengantar.

Epistemologi Islam menjadi penting untuk dikaji lebih jauh dan mendalam sebagai sebuah alternatif baru terhadap sistem epistemologi Barat yang begitu mendominasi wacana epistemologi kontemporer, tak terkecuali di Indonesia.

Menurut Mulyadi Kartanegara, epistemologi Islam dan filsafat ilmu, kalau memang mau dibedakan, ditulis oleh sarjana Indonesia masih bercorak Barat, hanya satu atau dua karya epistemologi Islam yang dapat ditemukan di Nusantara ini.

Refleksi mistiko-filosofis dari sebuah perjalanan pengetahuan menjadi penting, agar epistemologi yang ada dalam filsafat Islam tidak selalu berjalan di ruang teologis, tanpa ada relasi wacana dengan sosial, antropologi dan psikologi.

Lebih lanjut Mulyadi Kartanagara menulis dalam buku Menyibak Tirai Kejahilan, Pengantar Epistemologi Islam, bahwa dari sudut isi dan analisis, karyakarya tersebut belum betul-betul mewakili intisari epistemologi Islam. Dalam konteks inilah, perlu untuk mengkaji epistemologi sebagai alternatif

Peradaban Kristen, Islam, dan Yahudi, terj. Prismasohpi, (Yogyakarta: IrcisoD, 2001), h. 6. Pergulakan tentang wacana modernitas dan karakternya lihat F. Budi Hardiman, Melampaui Positivisme dan Modernitas, Dirkursus Filosofis tentang Metode Ilmiah dan Problem Modenitas, (Yogyakarta: Kanisius, 2003), h. 17 dan 52. terhadap kebutuhan umat Islam ${ }^{17}$ yang akhir-akhir ini mengalami krisisfilosofis.

Barat tidak harus dikesampingkan, akan tetapi ketika prestasi ilmiah yang begitu gemilang dari sains modern seharusnya tidak menghalangi untuk melihat sisi negatifnya dan mengkritisinya, misalnya dalam bentuk dampak dan implikasi sekulernya terhadap sistem kepercayaan agama Islam.

Sikap kritis dan waspada harus tetap menyertai sikap apresiatif terhadap sains modern. Nalar modern yang telah menimbulkan persoalanpersoalan serius, di samping kemanjuan yang diraihnya, terutama dari sudut pengetahuan sains, agar bangunan filosofis Islam tidak runtuh.

Perkembangan pemikiran yang berkembang di dunia Islam, daya kritis terhadap pemikiran ilmiah dan filosofis Barat, yang menurut Mulyadi Kartanegara telah terlalu berpihak pada nuansa positivistik dan materialistik telah menjadi segala-galanya, saat keterputusan dengan ilahi telah menjadi biang dari segala macam krisis kehidupan. Oleh karena itu, penting pengkajian sebuah nuansa mistikofilosofis menjadi penting untuk lebih kritis dibandingkan epistemologi Barat.

Apalagi ketika dibenturkan dengan masalah-masalah sosial tidak kunjung terselesaikan oleh filsafat Barat sebagai induk ilmu pengetahuan dan teknologi di Barat yang dalam batas-batas tertentu telah berhasil meraih pemahaman dan penguasaan atas alam material.

Epistemologi barat belum berhasil mengantarkan manusia dan problem

16 Mulyadhi Kartanegara, Menyibak Tirai Kejahilan, Pengantar Epistemologi Islam. (Bandung: Mizan, 2003), h. xxxi.

17 Ibid., Mulyadi Kartanegara, Menyibak Tirai..., h. xxxii. 
kemanusiaan pada makna kehidupan, lebih-lebih sumber pengetahuan itu sendiri. Sementara, filsafat timur khususnya Cina dan India yang penuh dengan tuntutan moral dan spiritualitas yang lebih mengutamakan nilai batiniah daripada lahiriah, tampaknya kehilangan pamornya pada abad teknokrasi ini ${ }^{18}$.

Mulyadi Kartanegara sebenarnya ingin mengkritik tokoh yang menolak adanya metafisika seperti yang ditulis dalam bukunya "Menyibak Tirai Kejahilan, Pengantar Epistemologi Islam", seperti Pierre de Laplace yang menyatakan bahwa Tuhan hanya sebagai hipotesa dan dia tidak membutuhkan hipotesa seperti itu karena sains bisa menjelaskan fenomena tersebut.

Charles Darwin yang menyatakan bahwa penciptaan alam semesta murni karena seleksi alam (natural selection) ${ }^{19}$. Dengan demikian tidak ada campur tangan dalam penciptaan alam semesta ini. Sigmund Freud yang menyatakan bahwa sebenarnya manusialah yang menciptakan tuhan, lebih jauh Freud mengatakan bahwa agama sebagai ilusi yang harus dimusnahkan dari peradaban ${ }^{20}$.

Dengan demikian Tuhan sebenarnya tidak ada, itu hanya rekayasa manusia saja. Emile Durkheim yang menyatakan bahwa Tuhan sebenarnya adalah masyarakat itu sendiri. Masyarakat bisa menentukan ada tidaknya segala sesuatu.

Tantangan yang lain juga terjadi di bidang lain seperti bidang spiritual, ekonomi, politik, kebudayaan dan ekologi. Tentu saja tantangan seperti ini tidak boleh dibiarkan tanpa kritik yang tajam, atau respons kritis dan kreatif

18 Damardjati Supadjar, Filsafat Sosial, Serat Sastra Gending, (Fajar Pustaka Baru, Yogyakarta. 2001), h. 6.

19 Mulyadi Kartanegara, Masa Depan Filsafat Islam: Antara Cita Dan Fakta. yang dapat dengan baik menjawab tantangan-tantangan tersebut secara rasional dan elegan, dan tidak sematamata bersifat dogmatis dan otoriter. Disinilah Mulyadi Kartanegara melihat bahwa filsafat Islam bisa berperan aktif dan signifikan dalam menjawab krisis spiritual filosofis.

Dalam hal ini Mulyadi Kartanegara menawarkan konsep "mistiko-filosofis" dalam menjawab tantangan epistemologi Islam ke depan. Apa itu mistiko-filosofis dan bagaimana wacana yang berkembang akan dibahas dalam artikel ini.

\section{Metode Penelitian}

Penelitian ini berbasis pustaka (library-based research), yaitu penelitian dengan mengumpulkan data, sekaligus meneliti referensi-referensi yang terkait dengan subjek yang dikaji, baik berupa makalah, buku, koran, jurnal, paper sekaligus wawancara dan disini peneliti menggunakan pendekatan filosofis ${ }^{21}$.

Sebagaimana dalam sebuah penelitian pustaka, biasanya yang dikumpulkan terdapat dua jenis data, yaitu data primer dan data sekunder. Di dalam buku ini juga terdapat data primer dan data skunder. Yang dimaksud dengan data primer adalah relevansi data yang cukup kuat dengan subjek yang dikaji. Sedangkan data sekunder adalah data yang disajikan sebagai pendukung bagi data primer. Dalam buku ini data primer adalah buku-buku karya Mulyadhi Kartanegara dan yang sekunder adalah buku-buku atau data-data lainnya, yang memiliki keterkaitan dengan subjek penelitian. Dalam penelitian ini akan menggunakan beberapa langkah pengumpulan data, antara lain:

${ }^{20}$ Lebih jelasnya lihat Kontowijoyo, Islam Sebagai Ilmu, Epistemologi, Metodologi, dan Etika, (Yogyakarta: Tiara Wacana, 2006), h. 8.

21 Peter Connolly (ed.) Aneka Pendekatan Studi Agama, (Yogyakarta: Lkis, 2002), h. 157. 
Penulisan artikel ini bersifat library-based research sehingga menelusuran upaya data didapatkan melalui pengumpulan melalui berbagai literatur yang relevan dengan tema yang diangkat. Data ini terbagi menjadi dua: satu: data Primer, ini merupakan data yang diperoleh secara langsung dari sumber aslinya. Sejauh ini peneliti berhasil mengumpulkan buku-buku karangan Mulyadhi Kartanegara. Di antaranya, Menyelami Lubuk Tasawuf, (Erlangga, 2006). Mengislamkan Nalar, Sebuah Respon terhadap Modernitas (Erlangga, Jakarta, 2007). Menyibak Tirai Kejahilan, Pengantar Epistemologi Islam (Mizan, Bandung, 2002), Menembus Batas Waktu, Panorama Filsafat Islam (Mizan, Bandung, 2003), Integrasi Ilmu, Sebuah Rekontroksi Holistik (Mizan, Bandung, 2005). Nalar Religius, Menyelami Hakikat Tuhan, Alam dan Manusia (Erlangga, 2007).

Dalam memperoleh data tentang epistemologi Islam, peneliti menggunakan teknik wawancara. Wawancara ini bersifat lentur dan terbuka, tidak terstruktur ketat, tetapi dengan pertanyaan yang semakin terfokuskan dan mengarah pada kedalaman informasi. Dalam hal ini, peneliti dapat bertanya kepada tokoh langsung, dan berbagai buku dan artikel yang penulis dapatkan dari majalah, jurnal, makalah seminar, situs di internet, dan lain sebagainya.

Setelah data pendukung terkumpul, maka langkah selanjutnya adalah tahap pengolahan data dan analisis untuk mendeskripsikan ide-ide pemikiran yang bertalian dengan tema yang akan diangkat secara gamblang, kemudian tema tersebut di analisis secara filosofis. Seluruh konsep yang ditawarkan dianalisa dengan menggunakan pendekatan filosofis.

Interpretasi sebagai metode pada dasarnya digunakan untuk mencapai suatu pemahaman yang benar mengenai mistiko-filosofis. Dengan menginterpretasi berarti seorang peneliti mencoba membangun sebuah pemahaman baru, analisis baru terhadap teks maupun pemikiran masa lampau yang diaktulkan (kontekstualisasikan) dengan kondisi atau konteks pemikiran saat ini.

\section{Basis Mistiko-Filosofis Pada Aspek Ontologis}

Aspek ontologis atau metafisika dalam filsafat Islam menjadi hal terpenting, sehingga filsuf Islam tetap mempertahankan dengan berbagai cara. Sejak pertama kali munculnya ontologi menjadikan cakrawala keilmuan filsafat semakin hangat antara filsuf Barat dan Islam, sebab ontologi yang membahas hal-hal yang irasional menjadikan filsuf Barat curiga dan terus meneliti yang pada akhirnya memiliki kesimpulan bahwa dunia irasional, immateri hanyalah sebuah ilusi dan halusinasi yang tidak penting untuk dijadikan pengetahuan ilmiah.

Akhirnya status ontologi ini memiliki karakteristik yang berbeda dengan Barat. Kalau Barat melihat sesuatu yang "ada" adalah sesuatu yang bisa dilihat indera, akan tetapi kalau di Timur melihat sesuatu yang "ada" tidak hanya yang bisa di indera, tapi di balik indera, seperti adanya sesuatu yang irasional, immateri atau yang mistik. "Ada" pun bermacam-macam, Ada dalam kemungkinan, Ada dalam kenyataan, Ada dalam Ada.

Ada dalam kemungkinan merupakan sesuatu yang belum disadarkan, sifatnya tiba-tiba ada. Ada dalam kenyataan ini merupakan sesuatu yang bisa di indera, seperti bentukbentuk dan materi. Ada dalam Ada adalah wajib ada, seperti Tuhan. Adanya Tuhan sebuah keniscayaan, sementara Adanya selain Tuhan hanya mungkin ada. 
Filsafat Islam selalu berbeda jalan dengan filsafat Barat, di samping ada pengaruh di antara keduanya. Dalam aspek ontologi perbedaan itu terjadi ketika pemikiran Islam dan Barat menempuh jalan yang berseberangan, salah satu bentuk perbedaan tersebut konsep tentang wujud (being, ada) dan realitas $^{22}$, karena dalam pemikiran mefafisika Islam memiliki perbedaan dengan yang ada di Barat.

Setiap cabang ilmu yang dihasilkan oleh sebuah epistemologi tidak akan mencapai status ilmiah yang sah, kecuali status ontologis objeknya jelas dan diakui. ${ }^{23}$ Orang yang tidak mengakui status ontologi sebagai objek-objek metafisika, bagaimana akan sampai pada pemahaman atau pengetahuan tentang objek itu sebagaimana adanya. Jika tidak bagaimana mungkin mendapatkan pengetahuan sebagaimana adanya padahal ia tidak ada. Tentu yang diyakini tidak ada tidak bisa diperoleh pengetahuan yang positif, karena:

Pohon-pohon perjalanan

Bergelar di atas mataku yang kagum

Lantaran satu huruf saja

Harus kupersiapkan ribuan buku dan refleksi

Untuk sampai di batas pengertian yang paling dalam. ${ }^{24}$

Banyak filosof Barat yang meragukan keberadaan status objek

\footnotetext{
22 Istilah wujud menurut Sayyed Hossein Nasr sebagaimana dikutip oleh Syaifan Nur bahwa yang digunakan dalam filsafat Islam tradisional tidak bisa dipahami hanya diterjemahkan ke dalam bahasa Enggris sebagai existence, tetapi sekaligus Existence, being, atau Being. Masing-masing istilah ini memiliki makna yang spesifik dalam konteks metafisika Islam. Istilah existence menunjuk kepada realitas segala sesuatu yang selain Wujud Mutlak, sedangkan Existence menuju kepada emanasi pertama dari Wujud Mutlak, atau yang biasa disebut sebagai al-faid al aqdas (emanasi yang suci). Adapun istilah Being menujuk kepada yang wajib al-wujud (Wujud Mutlak), sedangkan being merupakan suatu konsep
}

ontologis atau objek metafisika. Tidak heran kemudian kalau hanya memasukkan ilmu-ilmu empiris sebagai objek pengetahuan sains mereka dengan tegas menolak metafisika bahkan dikatakan metafisika itu ilusif. 25

Sementara di dunia Islam metafisika memiliki ruang yang masih hidup karena ilmuwan dan filsuf Islam telah dan masih mempertahankan sebagai objek pengetahuan yang memiliki peranan penting bagi keberlangsungan pengetahuan keislaman.

Islam sebagai agama memiliki nilai-nilai universal bagi kehidupan manusia sebenarnya telah memberi jalan cukup jelas tentang keberadaan mistik yang gaib itu. ${ }^{26}$ Metafisika sebagai cabang filsafat yang mencoba menjelajahi dunia rohani atau alam gaib yang menurut Islam harus diyakini kebenarannya oleh setiap Muslim, seperti, Tuhan, akhirat, roh, alam barzah, malaikat, surga, neraka, jin, dan sebagainya. Namun tentu saja, kepercayaan pada yang gaib tersebut tidak bisa diajarkan secara dogmatis belaka, melainkan harus disampaikan melalui argumen-argumen rasional yang rupanya telah menjadi tuntutan zaman, melalui analisis logis dan sistematis.

Keilmuan yang berada di dalam lembaga akademik yang menekankan pendekatan intelektual dan sekaligus

universal yang mencakup seluruh tingkatan realitas, baik yang berupa ciptaan maupun Wujud Mutlak, Syaifan Nur, Filsafat Wujud Mulla Sadra, (Yogyakarta: Pustaka Pelajar, 2002), h. 205.

23 Mulyadhi Kartanegara, Minyibak Tirai Kejahilan, Pengantar Epistemologi Islam, (Bandung: Mizan Media Utama, 2003), h. 42.

24 Matroni Muserang, "Pintu 08", dalam Minggu Pagi, No 45 TH 66 Minggu 1 Februari 2014, h. 07.

25 Ibid., Mulyadhi Kartanegara, Minyibak Tirai Kejahilan..., h. 43.

26 Ahmad Tafsir, Filsafat Ilmu: Mengurai Ontologi, Epistemologi, dan Aksiologi, (Bandung: Rosdakarya, 2012), h. 126. 
lembaga religius yang menekankan spiritualitas, sudah seharusnya memiliki visi (cara pandang) metafisika yang handal karena dalam dunia modern, metafisika mendapat serangan yang gencar dan radikal dari para ilmuwan dan pemikir (filosof) Barat sekuler. Selain itu, dikarenakan kebutuhan mendesak akan bangunan metafisik yang kokoh dari orang-orang modern agar mengetahui hakikat kehidupan yang sesungguhnya ${ }^{27}$.

Tauhid sebagai formula konvensional dalam agama Islam yang menjadi prinsip paling dasar dan urgen untuk mempersatukan ilmu ketuhanan dan ilmu kemanusiaan. Dalam perkembangannya, formula tauhid tersebut begitu banyaknya para tokoh dari sufi, filsuf, fuqaha, yang merumuskan dan mengartikannya.

Para teolog dan fuqaha cendrung mengartikan secara harfiah "tidak ada Tuhan yang wajib di sembah kecuali Allah"28, namun dalam basis mistikofilosofis dalam aspek ontologis akan dimaknai sejalan dengan pendekatan filosofis karena dalam pendekatan inilah tauhid akan menjadi formula yang menyegarkan dalam perkembangan pengetahuan ontologis.

Berbeda dengan pengertian di atas, para filsuf Islam memiliki pengertian tersendiri tentang keesaan Tuhan. Keesaan Tuhan bagi para filsuf haruslah simple, tidak boleh tersusun dari apa pun kecuali zat-Nya sendiri. ${ }^{29}$ Ibnu Sina misalnya yang mengartikan keesaan Tuhan sebagaimana di kutip oleh Mulyadhi Kartanegara bahwa pada

27 Mulyadhi Kartanegara, Nalar Religius: Memahami Hakikat Tuhan, Alam dan Manusia, (Jakarta: Penerbit Erlangga, 2007), h. 111.

28 Mulyadhi Kartanegara, Integrasi Ilmu, Sebuah Rekontruksi Holistik, (Bandung: Arasy Mizan, 2005), h. 33.

${ }^{29}$ Ibid., Mulyadhi Kartanegara, Integrasi Ilmu..., h. 33.

30 Ibid., Mulyadhi Kartanegara, Integrasi Ilmu..., h. 33. diri Tuhan esensi dan eksistensi adalah sama dan satu, ${ }^{30}$ sedangkan pada wujud yang selainnya, esensi dan eksistensi merupakan dua hal yang berbeda.

Inilah yang kemudian melahirkan banyak konsep mistik-filosofis yang gawangi oleh Ibn Arabi yang dilanjutkan oleh Mulla Shadra yang keduanya memiliki sisi yang berbeda. Ibn Arabi mengartikan sebagaimana dikutip oleh Mulyadhi Kartanegara bahwa alam ini tidak lain daripada manifestasi dari sifat-sifat, nama-nama, dan kerja Allah. ${ }^{31}$

Alam pada dirinya sendiri tidak memiliki realitas, karena Tuhanlah yang memberi realitas yang sebenarnya, lalu bermanifestasi kepada alam dan kemanusiaan. Seperti yang dikatakan Kuswaidi Syafi'ie bahwa alam semesta adalah imajinasi Tuhan dan dari kesepian Tuhan $^{32}$ atas maha sepinya Tuhan maka alam dan manusia diciptakan. Tuhanlah satu-satunya realitas sejati, makanya Tuhan disebut sebagai Sang Kebenaran, Sang realitas yang sebenarnya.

Seringkali seseorang lupa bahwa alam semesta itu ada yang mengadakan, tiba-tiba manusia langsung melihat alam ini nyata, tapi apakah alam semesta ini benar-benar nyata? Padahal alam semesta hanya imajinasi Tuhan. Ketika karya ini berasal dari imajinasi sesungguhnya tidak kekal dan tidak abadi. Kekekalan dan keabadian yang sebenarnya berada di Allah. Maka tidak heran kalau para sufi terus berjuang untuk naik dan mencari Tuhan melalui berbagai cara dan metode yang ada.

31 Ibid., Mulyadhi Kartanegara, Integrasi Ilmu..., h. 34.

${ }^{32}$ Kuswaidi Syafi'ie ketika mengisi seminar nasional yang diadikan Badan Eksekutif Mahasiswa Jurusan (BEM-J) Bahasa dan Sastra Arab oleh Fakultas Adab dan Ilmu Budaya di teatrikal Pusat Bahasa UIN Sunan Kalijaga Yogyakarta, pada tanggal 20 Desember 2013, jam 10. 
Dimulai dari tasawuf (pencarian, titik beranjak), sebagai salah satu cabang ilmu Islam yang menekankan dimensi atau aspek spiritual dari Islam, maka tasawuf merupakan dunia spiritual yang lebih menekankan aspek batin daripada aspek lahir.

Tasawuf sebuah dunia batin yang di dalamnya berisi orang-orang sufi yang mencari hakikat Tuhan. Orang sufi percaya bahwa dunia batin lebih tinggi daripada dunia jasmani. Itulah mengapa orang sufi terus berjuang untuk sampai pada hakikat yang sebenarnya yaitu Tuhan.

Hakikat (ontologis), para mistikus menyebut dirinya sebagai ahli hakikat. Penyebutan ini sebenarnya memiliki makna spirit yang sungguh-sungguh bahwa dirinya akan menemukan hakikat yang sebenarnya yaitu Allah.

Bagi mereka hakikat yang sebenarnya bukanlah alam semesta ini, akan tetapi Tuhanlah satu-satunya yang hakiki. Maka aspek tasawuf, syariah, tauhid, kesadaran akan adanya yang nyata, merupakan ransangan untuk sampai pada hakikat yang sebenarnya.

Tujuan dari perjalanan sufi untuk sampai ke alam hakikat perlu adanya perjalanan syariah atau dengan bahasa lain penting bagi seorang mistikus untuk tidak meninggalkan sisi sosialnya, bagaimana pun sisi sosial ini penting sebagai salah satu jalan untuk sampai pada hakikat. Inilah sebenarnya yang diinginkan mistiko-filosofis sebagai konsep yang penting untuk dilanjutkan dan dikembangkan.

Ma'rifat (jalan untuk sampai ke pengetahuan sejati), ma'rifat adalah sejenis pengetahuan dengan mana para sufi menangkap hakikat atau realitas yang menjadi obsesi mereka. ${ }^{33}$ Ma'rifat ini berbeda dengan jenis pengetahuan

${ }^{33}$ Mulyadhi Kartanegara, Menyelami Lubuk Tasawuf, (Jakarta: Erlangga, 2006), h. 10.

34 Ibid., Mulyadhi Kartanegara, Menyelami Lubuk ..., h. 16. yang lainnya, karena pengetahuan ini menankap objeknya secara langsung, tidak melalui representasi atau gambar dari objek penelitian.

Ma'rifat dalam hal ini bukan manafikan ilmu yang kemudian ilmu pengetahuan tidak benar, akan tetapi ma'rifat memiliki isi dan metode yang berbeda. Perbedaannya ilmu pengetahuan didapatkan dari otoritas orang lain, baik dari guru, kiyai, ulama, dosen, pengalaman, ayat-ayat dan buku.

Tarekat (berjalan di jalan spiritual), jalan di sini dimaknai sebuah jalan spiritual menemui Tuhan. Jalan tentu memiliki waktu yang menggiringinya, karena bagaimana pun untuk sampai pada Tuhan ada orang yang harus menempuh sebulan untuk sehari perjalanan. Ada yang merayap seperti semut. Ada yang menggambarkan sebagai burung rajawali yang bisa dengan cepat tiba di tangan Tuhan. ${ }^{34}$

\section{Aspek Epistemologis}

Selama ini epistemologi atau "teori ilmu pengetahuan" Islam merupakan bidang yang diabaikan untuk tidak mengatakan tidak diperhitungkan, artinya kajian epistemologi dalam artian yang sesungguhnya kurang mendapat apresiasi yang wajar ${ }^{35}$, jadi wajar kalau sampai detik ini ruang epistemologi Islam masih "sepi" dari wacana pemikiran keislaman.

Penting kemudian epistemologi dijadikan jalan untuk menjelaskan bagaimana mistiko-filosofis memberi jawaban dari perspektif epistemologi Islam. Sebuah cara untuk menemukan realitas sejati tanpa mengesampingkan nilai-nilai filosofinya.

35 Amin Abdullah, Studi Agama, Normativitas atau Historisitas (Yogyakarta: Pustaka Pelajar, 2002), h. 252. 
Aktivitas jiwa manusia yang serba ingin tahu tentang hal-hal di luar dirinya semakin mengukuhkan adanya kehidupan mistik, sejak masa primitif sampai masa modern ini kenyataannya mistik tetap digunakan sekalipun dalam kondisi tertutup. ${ }^{36}$ Sebagaimana dikutip oleh Ahmad Tafsir, tokoh-tokoh mistik kebanyakan sufi-sufi besar Ibnu Khaldun (Muqaddimah 1981: 66-694) dan Sihristany (al-Milal wa al-Nihal, tt 260-262) mengakui dunia mistik yang menggunakan kekuatan rohaniah selalu muncul dari orang-orang sufi yang selalu mengulah kekuatan spiritual ${ }^{37}$ untuk sampai pada Realitas yang sebenarnya.

Memasuki abad komtemporer, epistemologi Islam ditantang untuk mampu merumuskan visi epistemologi Islam yang jelas dan bersumber dari pandangan fundamental Islam. Setidaknya mampu mencakup aspekaspek ruang lingkup dan klasifikasi ilmu, sumber, serta metodologi ilmu yang mampuni, maka epistemologi Islam ini menjadi penting.

36 Ahmad Tafsir, Filsafat Ilmu: Mengurai Ontologi, Epistemologi, dan Aksiologi, (Bandung: Rosdakarya, 2012), h. 125. 127.

37 Ibid., Ahmad Tafsir, Filsafat Ilmu..., h.

38 Ma'rifah menurut Rumi sebagaimana dikutip Mulyadhi Kartanegara bahwa sebuah modus pengetahuan yang istimewa (sejati), yang berbeda, baik dalam isi maupun metode, dengan modus pengetahuan yang selama ini kita kenal. Ma'rifah dilukiskan Rumi sebagai "mutiara" di laut. Berbondong-bondong orang datang ke laut untuk mendapatkan mutiara itu. Orang-orang ribut dan bertanya-tanya dimana sang mutiara berada. Kami telah mencarinya kemana-mana, tetapi tidak ditemukan. Seorang bijak datang dan berkata kepada mereka, Mutiara tidak bisa ditemuakan hanya dengan melihat laut karena mutiara ada di dasar laut yang dalam. Lalu ada orang lain yang mempunya ide untuk menimba laut, supaya airnya kering an mutiara dapat ditemukan di sana. Tapi kata orang bijak itu lagi, laut tidak mungkin kering dengan ditimba airnya, akan selalu melelahkan. Satu-satunya cara untuk
Sejak dua ribu tahun yang lalu epistemologi Islam memang belum ada yang membahas Nazhariah al-Ma'rifah atau Teori pengetahuan ${ }^{38}$, akan tetapi sebagian besar persoalan-persoalan yang menyangkut epistemologi ditulis secara terpisah dalam berbagai pembahasan yang berkenaan dengan ilmu, pengetahuan, rasio, logika dan berbagai bentuk pemikiran lainnya.

Ciri menonjol dari epistemologi Islam adalah bukan hanya pengalaman indera $^{39}$ saja yang dipandang sebagai "riil atau nyata" tetapi juga pengalaman akal dan intuisi sebagai bagian yang tak terpisahkan dari instrumen untuk mendapatkan pengetahuan. Karenanya, masing-masing pengalaman itu patut mendapat perhatian dalam visi epistemologi Islam. Benar apa yang dipertanyakan oleh Sari Nuseibeh bahwa dalam pengertian apakah pengetahuan manusia berbeda dengan pengetahuan? Apakah peran manusia yang berpengetahuan ${ }^{40}$

Dengan dua pertanyaan di atas barangkali menjadi acuan untuk

mendapatkan mutiara tersebut adalah dengan menyelami. Kita membutuhkan penyelan yang ulung untuk bisa berenang sampai ke dasar laut. Akan tetapi karena mutiaran terletak di dalam kerang, sementara tidak semua kerang berisi mutiara, kita membutuhkan bukan hanya penyelam ulung, melainkan juga keberuntungan, Mulyadhi Kartanegara, Menembus Batas Waktu, Panorama Filsafat Islam, (Bandung, Mizan, 2005), h. 23. Lihat juga Murtadha Muthahhari dalam Muhammad Jawab Bafaqih (terj.) "Mengenal Epistemologi" (Jakarta: Lentera, 1989), h. 22.

39 Ibid., Murtadha Muthahhari. Mengenal..., h. 51. Indera merupakan hal yang penting, bahkan ada ungkapan dari Aristoteles "Barang siapa yang kehilangan satu indera, maka ia telah kehilangan satu ilmu" (man faqaha hissa faqad faqaha ilman). Setiap manusia yang kehilangan salah satu bentuk inderanya, maka ia juga akan kehilangan salah satu bentuk epistemologi.

40 Sari Nuseibeh, "Epistemologi", dalam Sayyed Hossein Nasr (ed.), Ensiklopedi Tematis Filsafat Islam (Bandung: Mizan, 2002), II: 1139. 
memahami kemampuan Tuhan di samping Kuasa juga mengetahui, dan untuk mengetahui pengetahuan yang benar dapat dicapai dengan bantuan Ilahi atau melalui rahasia semesta, karena Islam meyakini Tuhan merupakan penyebab pertama dan terakhir dan Tuhan mengetahui tatanan yang paling terkecil pun dalam tataran ontologis. Maka dapat dikatakan bahwa sifat dari Tuhan adalah pengetahuanNya dan umat Islam meyakini bahwa pengetahuan sejati adalah pengetahuan tentang Tuhan.

Wilayah Tuhan dan manusia berbeda dalam mendapatkan pengetahuan, Tuhan sebagai pencipta pengetahuan dan kreator utama sebagai pencipta ide dan menciptakan cara untuk disampaikan pada manusia, sementara manusia menciptakan pengetahuan dan menerapkannya juga tapi masih memiliki keterbatasanketerbatasan seperti yang dikatakan alKindi sebagaimana dikutip oleh Ahmad Zainul Hamli bahwa filsafat memiliki keterbatasan. ${ }^{41}$

Berdasarkan kepercanyaankepercayaan tersebut maka dapat dikatakan bahwa manusia mampu memperoleh sebagian kemampuan Tuhan. Namun kepercayaankepercayaan tersebut tidak serta-merta dijadikan pengetahuan, akan tetapi harus dikritisi sebagai bagian perjalan akal dan hati, karena bagaimana pun pengetahuan tidak akan dijelaskan tanpa ada akal yang membantunya untuk menjelaskan pengetahuan tentang Tuhan. Dari sinilah kemudian basis epistemologi dari mistik-filosofis

41 Ahmad Zainul Hamdi, Tujuh Filsuf Muslim, Pembuka Pintu Gerbang Filsafat Barat Modern, (Yogyakarta: Lkis, 2004), h. 56.

42 Abd Hakim dan Yudi Latif, Bayangbayang Fanatisisme, Esai-esai untuk Mengenang Nurcholish Madjid, (ed.), (Jakarta: Pusat Studi Islam dan Kenegaraan (PSIK), 2007), h. 79. menemukan ruang dialektika yang saling menyapa antara akal dan hati.

Maka, basis mistiko-filosofis dalam epistemologi Islam ingin memcoba memberikan sumbangan terhadap perkembangan peradaban Islam dalam menjawab persoalanpersoalan yang terkait dengan sains modernitas, seperti yang digelisahkan Mulyadhi Kartanegara dalam tulisantulisannya.

Apa yang ditulis oleh Fritjof Capra sebagaimana dikutip oleh Kautsar Azhari Noer ${ }^{42}$ bahwa ada dua jenis pengetahuan yaitu pengetahuan rasional diperoleh melalui berpikir rasional sedangkan pengetahuan intuitif diperoleh melalui berpikir imaginal.

Unsur rasional dari riset sebenarnya tidak akan berguna bila tidak dilengkapi oleh intuisi yang memberi para ilmuwan pemahamanpemahaman baru dan membuat mereka kreatif. ${ }^{43}$ Mistikus Timur menurut Fritjof Capra sebagaimana dikutip Kautsar Azhari Noer bahwa mengungkapkan pengetahuan mereka dengan kata-kata dengan bantuan mitos-mitos, simbolsimbol, gambaran-gambaran puitis atau pernyataan-pernyataan paradoksikal. ${ }^{44}$

Basis epistemologi yang selama ini berjalan di ranah tekstual dan ritual sudah saatnya untuk mempertimbangkan konteks dimana epistemologi itu hidup. Konteks sebagai tempat atau wadag untuk mentransformasikan keilmuan menjadi relevan termasuk di dalamnya menerapkan konsep-konsep mistik dan falsafah $^{45}$ sebagai alat untuk mempertemukan indera, akal dan hati.

43 Ibid., Abd Hakim dan Yudi Latif, (ed.). Bayang-Bayang Fanatisisme, Esai-esai untuk Mengenang Nurcholish Madjid, h. 79.

44 Ibid., Abd Hakim dan Yudi Latif, BayangBayang Fanatisisme..., h. 80.

45 Lihat b.Arab, falsafah. Filsafat. Usaha untuk menafsirkan Islam dalam terma rasionalisme Yunani Kono, Karen Armstrong, Sejarah Tuhan, Kisah 4.000 Tahun Pencarian 
Pengalaman mistik merupakan salah satu upaya untuk memberikan pengetahuan baru dan bisa dijadikan sumber pengetahuan, di sinilah peran penting epistemologi Islam bagi perkembangan mistik ke depan, dari sinilah terlihat betapa epistemologi Islam begitu penting dalam memberikan angin segar terhadap perjalanan mistiko-filosofis.

Angin segar inilah yang sebenarnya diharapkan untuk mendamaikan perjalanan mistikfilosofis, karena mistiko-filosofis merupakan tawaran Mulyadhi Kartanegara untuk mendamaikan dan saling mengenal bahwa Barat dan Timur memiliki keilmuan yang berbeda.

\section{Aspek Aksiologis}

Aksiologi adalah ilmu yang mempelajari cara-cara yang berbeda bagaimana sesuatu dapat baik dan buruk, aksiologi juga sebuah filsafat yang mempelajari cara untuk mendapatkan atau menegakkan sumbu kesemestaan. ${ }^{46}$ Oleh karena itu hakikat nilai menurut Kattsoff sebagaimana dikutip oleh Damardjati Supadjar ada empat, pertama nilai sebagai kualitas empiris dan tidak dapat di definisikan, kedua nilai sebagai objek suatu kepentingan, ketiga nilai sebagai hasil pemberian nilai dan yang keempat nilai sebagai esensi. ${ }^{47}$

Nilai sebagai ilmu dan amal tidak bisa dipisahkan dalam etika Islam. Memiliki ilmu saja tidak cukup menjamin seseorang bisa menjadi baik moralnya kalau tindakan moralnya tidak berdasar pada pengetahuannya. Demikian juga, amal tanpa ilmu tidak akan mencapai tujuan yang diharapkan.

Tuhan dalam Agama-Agama Manusia, (Bandung: Mizan, 2013), h. 587.

46 Damardjati Supadjar, "Sosok dan Perspektif Filsafat Islam Tinjauan Aksiologis", dalam Irma Fatimah (ed.), Filsafat Islam Kajian
Al-Farabi, sebagaimana dikutip Mulyadhi Kartanegara, sambil mengkritik Aristoteles yang percaya bahwa ilmu dapat memberi jalan manusia kepada kebahagiaan mengatakan bahwa kebahagiaan sejati hanya bisa dicapai ketika terjadi perpaduan antara ilmu-ilmu teoretis dan ilmu-ilmu praktis. Dengan kata lain, perpaduan antara ilmu dan amal ${ }^{48}$ harus selalu berjalan mesra dan beriringan.

Aspek aksiologi dalam hal ini lebih pada makna etiket atau pengaplikasian dari ontologi dan epistemologi, artinya aspek aksiologi dalam mistiko-filosofis merupakan ranah aksi, karena aplikasi dalam sebuah pengetahuan sangat penting, mengingat adanya pendekatan sosiologi yang harus dipertimbangan dari nilai-nilai mistik dan filsafat.

Buat apa berpikir kalau tidak ada aksinya dan buat apa masuk dalam dunia mistik jika hanya untuk diri sendiri, maka kemudian, memberikan pemahaman dan pengaplikasian dalam ranah sosial. Di sinilah letak tanggungjawab manusia dalam memberikan pengetahuan kepada masyarakat.

Inilah sebenarnya yang diinginkan oleh Mulyadhi Kartanegara yaitu kemesraan mistik dan filosofis atau dengan kata lain mistik dan filsafat. Hanya saja Mulyadhi Kartanegara tidak menjelaskan bagaimana cara untuk memesrakan dua ikon pengetahuan ini? Kalau hanya untuk mendapatkan nilai dari mistik dan filosofis, maka dengan sendiri hal itu sudah mengandung nilai, akan tetapi bagaimana cara untuk melihat dan menggali nilai tersebut membutuhkan pengetahuan lain, dan dalam hal ini Mulyadhi Kartanegara lagi-

Ontologis, Epistemologis, Aksiologis, Historis, Perspektif, (Yogyakarta: LESFI, 1992), h. 56.

47 Ibid., Damardjati Supadjar, Sosok dan Perspektif..., h. 57.

48 Ibid., Mulyadhi Kartanegara, Nalar Religius..., h. 120. 
lagi tidak memberikan jawaban, maka dalam persoalan nilai inilah yang harus diperhitungkan, karena bagaimana pun aspek aksiologis dalam mistiko-filosofis penting untuk di eksplorasi lebih dalam.

Pembaca akan bertanya-tanya untuk apa mistiko-filosofis dihadirkan sebagai wacana kalau tidak memberikan nilai universal terhadap perjalanan pengetahuan mistik dan falsafah? Dalam hal ini peneliti akan mencoba untuk melihat dari perspektif aksiologi sebagai aktualitasasi dari perjalanan intelektual muslim dalam dunia filsafat.

Mistik yang selama ini berada di tangan seorang sufi masih belum menjadi pengetahuan yang banyak dipahami oleh masyarakat, seolah-olah ketika mendengar kata sufi, seorang sufi dianggap orang yang hanya berkutat di dunia Tuhan, tanpa peduli terhadap kemanusiaan, maka dari itulah filsafat masuk ke rumah mistik untuk membantu menjelaskan sejauh kemampuan filsafat menjelaskan pengalaman mistik dari seorang sufi. Karena sejauh pencarian peneliti Mulyadhi Kartanegara belum menulis aspek aksiologi dalam tulisantulisannya, maka dari itu peneliti merasa penting untuk menjelaskan secara aksiologi ini sebagai cabang filsafat yang menjelaskan tentang nilai.

Mistiko-filosofis dilihat dari perspektif aksiologi ini penting untuk melihat sumbangsih pemikiran yang diusung oleh Mulyadhi Kartanegara. Sebagai sebuah nilai, mistiko-filosofis memiliki nuansa yang berbeda karena wacana yang diusung sebenarnya wacana lama hanya nuansa keberbedaan itu terletak pada usahanya untuk merefleksikan nilai-nilai mistik dan filsafat yang kedua item ini merupakan hal yang berarti dalam memberikan peta dan pintu keluar dari kungkungan modernitas yang membuat manusia masa kini dilelapkan oleh materialitas dan rasionalitas.

Wacana mistik-filosofis dewasa ini menjadi momok yang sangat dominan, karena masih bisa melihat alam dan wacana tersebut akan terus hangat untuk dijadikan bahan refleksi bersama, mengingat dunia Muslim semakin hari semakin akan mengalami degradasi aksiologi (kemerosotan nilai). Ini terlihat manusia masa kini yang enggan membaca buku, refleksi, lebih banyak bermaen game daripada baca buku. ${ }^{49}$

Inilah sebenarnya yang akan berdampak pada bangunan awal pemikiran, sehingga pada akhirnya dunia mistik akan mengalami degradasi yang cukup dahsyat. Kalau boleh berkaca pada Barat pemikiran Muslim sudah kalah jauh, sebab Barat mengalami perkembangan yang cukup pesat saat terbebas dari tradisi skolastik yang didominasi elit gereja. Tapi sudah saatnya pemikiran keislaman mampu bangun dari kelelahan sehingga tidak mengalami nir-nilai yang juga berdampak pada masyarakat.

Dalam hal ini, pesatnya perkembangan sains dan teknologi dalam satu sisi dapat mengantarkan untuk kesejahteraan materiilnya, tetapi di sisi yang lain, paradigma sains dan teknolgi dengan berbagai pendekatan dewasa ini sudah tidak lagi mementingkan sesuatu yang metafisik (mistik), sehingga telah menyeret pada degradasi aksiologi dan kegelapan deminsi spiritual. Inilah yang dikhawatirkan peneliti sebagai pribadi dan manusia secara umum dewasa ini, yang ditandai dengan kematian budaya humanisme dan hilangnya etos religiusitas dalam kehidupan. 
Keadaan sosio-budaya, sebagai manifestasi empirik dari pemikiran, yang sebaiknya didasarkan pada nilainilai normaif Ilahiyah, semakin lama semakin jelas bahwa sudah mengalami pergeseran yang sungguh berarti. Nilainilai altruistik (cinta kasih) tergeser dengan nilai individualistik. Hal ini menarik akan tumbuhnya kompetensi hidup yang sangat tajam, sehingga wajar kalau masih terjadi kekerasan atas nama agama dan atas nama pengetahuan serta kebenaran.

Kekhawatiran itu tentunya beralasan, karena dewasa ini, seperti apa yang diungkap oleh Prof. Cyril Edwin Blak dalam "Change as Conditiou of Modern Life" sangat kuat dalam merombak struktur nilai-nilai yang akhirnya memberi ruang akan hadirnya nilai baru, dan pandangan baru yang akhirnya mengkristal dalam norma sosio-budaya yang cenderung tidak manusiawi. Kristalisasi sosio-budaya seperti itu sangat lengket dengan perkembangan iptek yang ditransformasikan melalui proses pendidikan yang bernuansa parsial mengenai pengetahuan yang tidak lagi berpijak pada nilai-nilai Ilahiyah, yang pada akhirnya lahir konsekuensi baru sebagai problematika humanisme secara holistik-universal.

Dalam transfomasikan nilai yang krusial, ternyata orientasi keilmuan Islam masih memiliki peranan penting dalam sebuah harapan untuk meluruskan penyimpangan yang terjadi dalam sosio-budaya yang berkenaan dengan persepsi ilmu dan diimplementasikan dalam kehidupan praksis manusia.

Sejenak umat Islam dihadapkan pada persoalan pemikiran dan keilmuan yang mana dan bagaimana yang memberikan pandangan yang utuh

50 Ibid., Matroni el-Moezany, "Degradasi Aksiologi Pendidikan", dalam Koran Merapi, Jum'at Wage, 16 Mei 2008, h. 8. sebagai jembatan dalam upaya mempertahankan nilai keagamaan dengan menekankan harmonisasi hubungan dengan alam, dan lingkungan, yang dijiwai oleh nilai-nilai normatif Ilahiyah. ${ }^{50}$

Berkenaan dengan ilmu dan moral, Jujun S. Suriasumantri bahwa ilmu yang membuat jadi pandai, teknologi memberi kemudahan, namun semuanya tidak membawa bahagia dan hanya sepi dan kengerian yang terbayang. Kenyataanya hal itu adalah karena masing-masing pengetahuan itu terpisah. Ilmu terpisah dari moral, moral terpisah dari seni, seni pun terpisah dari ilmu. Manusia hanya memiliki pengetahuan yang parsial.

Melihat perkembangan ilmu yang tidak membawa kemaslahatan, Albert Eistein menyampaikan sebuah pernyataan kolektif, di kala ia berpesan kepada mahasisawanya bahwa "Mengapa ilmu yang sangat indah ini, yang mengenal kerja dan membuat hidup lebih mudah, hanya membawa kebahagiaan yang sedikit kepada kita? Ilmu yang seharusnya membebaskan kita dari pekerjaan yang melelahkan malah menjadikan kita manusia budakbudak mesin?". 51

Secara representatif, pernyataan di atas merupakan fenomena dunia empiris. Dimana dunia dirasakan semakin lama tak lagi menjungjung nilai harmonisasi, jauh terlepas dari idealisasi hidup yang dituntunkan Tuhan. Pengetahuan Islam dan segala muatan ilmu digambarkan sesuatu yang dinamis penuh dengan daya kreatif. Tapi tidak menjanjikan hadirnya kebahagiaan sejati dalam diri.

Dalam kekhawatiran Karl Jaspers misalnya mengungkap bahwa dunia benar-benar mengalami dispiritualisasi yang tunduk kepada rezim kemajuan

51 Ibid., Matroni el-Moezany, "Degradasi Aksiologi Pendidikan", dalam Koran Merapi, Jum'at Wage, 16 Mei 2008, h. 8. 
tekonologi. Senada dengan kekhawatiran Eistein. Kals Jaspers menegaskan kembali bahwa manusia tampaknya mampu menghapuskan dirinya, untuk kehilangan dirinya sendiri serta mendapat kepuasan dalam keadaan yang impersonality (tanpa kepribadian). Akhirnya saat ini sedang perjalanan menunggu tenggelamnya manusia ke dalam mesin.

Dengan bahasa yang indah, semua itu karena miskinnya wawasan atau cakrawala aksiologi pemikiran pada seluruh deminsi keilmuan yang dikembangkan. Terdapat bentangan yang tajam dalam aspek rasionalitas dan aspek aksiologi, ke-shok-an budaya, agama, dan pemikiran tidak bisa ditutupi sebagai wujud kekejaman rasionalitas yang dihadirkan dari Barat.

\section{Kesimpulan}

Pemikiran Mistiko-Filosofis yang di usung oleh Mulyadi Kartanegara merupakan respon terhadap pemikiran Barat sekuler yang tidak mengakui adanya yang gaib, seperti Tuhan, Malaikat, Jin, dan hari kiamat serta keyakinan umat Islam. Namun hal ini juga dibantah pada abad berikutnya yaitu pada abad kontemporer yang sudah mengakui adanya yang gaib.

Mistiko-filosofis ini merupakan istilah yang di ambil dari tradisi Ibn alArabi yang dikembangkan Mulyadhi Kartanegara sendiri setelah menjalani proses perjalanan pemikiran, pembacaan yang mendalam dan refleksi filosofis terhadap filsafat Islam yang selama ini Mulyadhi Kartanegara geluti.

Mistiko-filosofis menurut Mulyadi Kartanegara merupakan sebuah ruang dimana terjadi pergulatan antara indera, akal dan hati yang saling berkaitan untuk memberikan ilmu pengetahuan terhadap manusia.

Tiga ikon inilah yang kemudian membentuk fondasi epistemologi Islam, dalam hal ini mistiko-filosofis, namun tiga hal ini selama ini dikatakan belum berjalan bermesraan dalam mendamaikan ilmu pengetahuan antara agama dan filsafat, sains dan agama, agama dan disiplin ilmu yang lain bahkan menciptakan jurang pemisah yang tajam. Seiring perjalanan sejarah pemikiran, jurang pemisah itu terus diupayakan untuk disinergikan dalam kesatuan dan untuk menghilangkan jurang pemisah tersebut menurut Mulyadhi Kartanegara adalah mistikofilosofis.

Seorang intelektual Muslim tidak cukup berhenti pada tataran teoritis, akan tetapi harus bergerak menuju pada peristiwa sejati jiwa (haqq al-yakin), artinya seorang Muslim harus terus berjalan menyebrangi segala lautan, teluk, dan jalan terjal yang memisahkan kepastian ilmu-ilmu teoritis dan kepastian dari pengetahuan gnostik yang terhayati dalam dirinya sendiri. Dalam dunia mistik seseorang harus mengatasi alam yang berfungsi sebagai tangga dan menjadikan sebagai penopang dalam perjalanan menuju cahaya. Tentu seseorang harus mau dan berani melakukan dan merenungkannya.

Dari semangat untuk mentransenden atau memistikkan realitas dan juga untuk menyatukan tiga ikon yang berseberangan itu, maka ide untuk memistikkan harus dimunculkan ke permukaan agar diketahui betapa banyak karya-karya mistik dan keseharian yang penuh mistik dan filsosfis.

Dengan berpikir dan berkarya baik sufi dan filosof akan mengungkapkan secara simbolis dan indah pengalaman berlayar di samudera spiritual. Dan pengalaman yang ditulis itu bukanlah karya fiktif, akan tetapi merupakan sebuah refleksi-refleksi filosofis selama pelayaran spiritual mereka di dunia realitas sejati. 
Bagi metafisikawan seperti Suhrawardi dunia materi atau dunia yang luas ini adalah negatif. Dunia ini adalah dunia kegelapan yang berada di batas terakhir cahaya yang paling redup setelah diredam oleh berjuta-juta "barzakh" yang memediasi antara Tuhan dan alam fisik.

Dengan demikian, realitas sejati adalah cahaya, sedangkan alam fisik adalah realitas yang nisbi dan tidak akan terwujud andaikan tidak ada cahaya. Cahaya-cahaya itu pun tidak akan pernah ada tanpa ada cahaya dari segala cahaya atau cahaya maha cahaya yaitu Tuhan, untuk tahu dan mengerti bahkan ingin memiliki pengalaman dan menemukan cahaya sejati yaitu dengan jalan mistik.

Ketika ketiganya belum berjalan bermesraan, maka untuk melihat implikasinya tidak bisa dilihat perkembangannya. Namun implikasi itu akan terlihat ketika kemudian implikasi mistiko-filosofis terhadap perkembangan metafisika kontemporer benar-benar memiliki epistemologi yang jelas, akan tetapi Mulyadhi Kartanegara tidak memberikan peta epistemologi yang jelas dalam mendamaikan ketiga ikon tersebut.

Misalnya

bagaimana

menjembatani dari indera, lalu akal kemudian hati, Mulyadhi Kartanegara hanya menyebutkan bahwa untuk menjadi epistemologi Islam yang utuh, maka tiga ikon ini harus berjalan bermesraan, tapi bermesraan yang seperti apa Mulyadhi Kartanegara tidak menjelaskan.

Padahal apa yang dilihat oleh indera tanpa adanya akal yang memberikan pemahaman, maka apa yang dilihat indera tidak dapat dipahami, dan hati tanpa indera dan akal timpang, maka dari itulah penting kemudian untuk berusaha mendamaikan antara ketiganya.
Implikasi inilah mistiko-filosofis cukup mampu memberikan implikasi terhadap perjalanan filsafat Islam, terutama dalam epistemologi. Mistikofilosofis sebuah istilah untuk melahirkan warna baru sebagai bentuk bahwa eksistensi filsafat Islam memiliki beragam wacana yang terus hidup dan berkembang, namun bentuk perkembangan pemikiran, mistikofilosofis mampu memberikan ruang yang cukup signifikan atau ruang untuk berdialog dengan perkembangan pemikiran yang selama ini terus berkembang dan hidup.

\section{DAFTAR PUSTAKA}

Abdullah, Amin. Studi Agama, Normativitas atau Historisitas, Yogyakarta: Pustaka Pelajar, 2002.

Abu el-Fadl, Khaled. Atas Nama Tuhan, Dari Fikih Otoriter dan Fikih Otoritatif, terj. R. Cedep Lukman Yasin, Jakarta: PT Serambi Ilmu Semesta, 2004.

Affifi, A.E. Filsafat Mistik Ibnu Arabi, Jakarta: Gaya Media Pratama, 1995.

Armsrtong, Karen. Sejarah Tuhan, Kisah 4.000 Tahun Pencarian Tuhan dalam Agama-Agama Manusia, terj. Zaimul Am, Bandung: Mizan Pustaka, 2013.

Asy'Arie, Musa. Filsafat Islam, Sunna Nabi dalam Berfikir, Yogyakarta: LESFI, 2002.

Azhari Noer, Kautsar. "Tuhan yang Diciptakan dan Tuhan yang Sebenarnya," PARAMADINA: Jurnal Pemikiran Pemikiran Islam., Vol. 1, Juli-Desember 1998.

B, Russell. The Problem of Philosophy, Los Angeles: Indo-European Publishing, 2010. 
Bagus, Loren. Kamus Filsafat, Jakarta: Gramedia Pustaka Utama, 2000.

Bakker, A dan Zubair, A. C. Metodologi Penelitian Filsafat, Yogyakarta: Kanisius, 1990.

Baneth, D.Z. "Apakah yang Dimaksud Muhammad Saw dengan Menamakan Agamanya "Islm"? dalam N.J.G. Kaptein (ed.), Sukarsi (penerj), Pandangan Barat Terhadap Islam Lama, Jilid 4, Jakarta: INIS, 1989.

C. Chittik, William. Kosmologi Islam dan Dunia Modern, terj. Arif Mulyadi, Jakarta: Mizan Publika, 2010.

Connolly, Peter. (ed.) Aneka Pendekatan Studi Agama, Yogyakarta: Lkis, 2002.

D. Hunnex, Milton. Peta Filsafat, Pendekatan Kronologis dan Tematis, terj. Zubair, Bandung: Teraju, 2004.

Danusiri, Epistemologi dalam Tasawuf, Pustaka Pelajar: Yogyakarta, 1996.

Davies, Paul. Membaca Pikiran Tuhan, Dasar-Dasar Ilmiah dalam Dunia yang Rasioanl, terj. Hamzah, Yogyakarta: Pustaka Pelajar, 2012.

Fakhri, Majid. Sejarah Filsafat Islam, terj. Mulyadhi Kartanegara, Jakarta: Pustaka Jaya, 1986.

Gazalba, Zidi. Sistematika Filsafat, Buku Pertama, Pengantar Kepada Filsafat, Jakarta: Bulan Bintang, 1992.

Ghazali, al. Misykat Cahaya-Cahaya, terj. Muhammad Bagir, Bandung: Mizan, 1984.

Ghazali, al.The Niche of Lihhts (Misykat al-Anwar): A Parallel EnglishArabic Texs, diterjemahkan, diberi pengantar dan catatan oleh David Buchman Provo, Utah: Brigham Young University Press, 1998.

Hady, Samsul. Islam Spiritualitas, Kesaksian Eksistensi, Malang: UINMalang Press, 2007.
Hakim, Abd dan Latif, Yudi. Bayangbayang Fanatisisme, Esai-esai untuk Mengenang Nurcholish Madjid, (ed.), Jakarta: Pusat Studi Islam dan Kenegaraan PSIK), 2007.

Hardiman, F. Budi. Filsafat Modern dari Machiavelli sampai Nietzsche Jakarta: Gramedia Pustaka Utama, 2004.

Hardiman, F. Budi. Heidegger dan Mistik Keseharian, Suatu pengantar Menuju Sein und Zeit, Jakarta: KGP, 2003.

Hardiman, F. Budi. Melampaui Positivisme dan Modernitas, Dirkursus Filosofis tentang Metode Ilmiah dan Problem Modenitas, Yogyakarta: Kanisius, 2003.

Hasan Enver, Ishrat. Metafisika Iqbal, Yogyakarta: Pustaka Pelajar, 2004.

Hossein Nasr, Sayyed. Integensi dan Spiritualitas Agama-Agama, terj. Suharsono (Jakarta: Inisiasi, 2004).

Hossein Nasr, Seyyed dan Leaman, Oliver. Ensiklopedi Tematis Filsafat Islam, Bandung: Mizan 2003.

Hossien Nasr, Sayyed. "Filsafat" dalam Ensiklopedi Oxpord, Dunia Islam Modern, diedit oleh John L Esposito, jilid 2, Bandung: Mizan, 2002.

Ian G Barbour, "Isu dalam Sains dan Agama", terj. Damayati, Yogyakarta: UIN Sunan Kalijaga, 2006.

James, William. Perjumpaan dengan Tuhan (terj.) Gunawan Adrianto, Bandung: Mizan Pustaka, 1982.

Kartanegara, Mulyadhi. Integrasi Ilmu, Sebuah Rekontruksi Holistik, Bandung: Mizan Pustaka, 2005. Menembuas Batas Waktu, Panorama Filsafat Islam, Bandung: Mizan, 2005. 
-----. Mengislamkan Nalar, Sebuah Respon terhadap Modernitas, (Jakarta: Erlangga, 2007).

-----. Menyelami Lubuk Tasawuf, Jakarta: Erlangga, 2006.

------. Menyibak Tirai Kejahilan, Pengantar Epistemologi Islam. Bandung: Mizan, 2003.

------. Nalar Religius: Menyelami Hakikat Tuhan, Alam dan Manusia, Jakarta: Erlangga , 2007.

-----.. "Argumen-argumen Adanya Tuhan" dalam jurnal PARAMADINA vol. I, No. 2, Jakarta: Paramadina, 1999.

Kontowijoyo, Islam Sebagai Ilmu, Epistemologi, Metodologi, dan Etika, Yogyakarta: Tiara Wacana, 2006.

Lewis, Bernard. Kemelut Peradaban Kristen, Islam, dan Yahudi, terj. Prismasohpi, Yogyakarta: IrcisoD, 2001.

Liang Gie, The. Pengantar Filsafat Ilmu, Yogyakarta: Liberty, 2000.

M Abu-Rabi, Ibrahim. Intellectual Origins Of Islamic Resurgence In The Modern Arab Word,

Muhajir, H. Noeng. Filsafat Ilmu: Positivisme, Post-Positivisme dan post-modernisme, Ed.2, Yogyakarta, Rake Sarasin, 2001.

Muthahhari S.M.H Thabathaba'I, Murtadha. Menapak Jalan Spiritual, terj. M.S Nasrullah, Bandung: Pustaka Hidaya, 1997.

Muthahhari, Murtadha. dalam Muhammad Jawab Bafaqih (terj.) "Mengenal Epistemologi" Jakarta: Lentera, 1989.

Nahrowi Tohir, Moenir. Menjelajahhi Eksistensi Tasawuf Meniti Jalan Menuju Tuhan, Jakarta: As-Salam Sejahtera, 2012.

Nasution, Harun. Filsafat dan Mistisisme dalam Islam, Jakarta: Bulan Bintang, 1978.

Nasution, Harun. Teologi Islam, Jakarta: UI-Press, 2012.
Nur, Syaifan. Filsafat Hikmah Mulla Shadra, Yogyakarta: RausyanFikr Institut, 2012.

Nurisman, Pemikiran Filsafat Islam Harun Nasution, Pengembangan Pemikiran Islam di Indonesia, Yogyakarta: Teras, 2012.

Nuseibeh, Sari. "Epistemologi", dalam Sayyed Hossein Nasr (ed.), Ensiklopedi Tematis Filsafat Islam, Jilid II, Bandung: Mizan, 2002.

Purwadianto, Agus. et al. Jalan Paradoks, Visi Baru Fritjof Capra tentang Kearifan dan Kehidupan Modern, Jakarta: Teraju, 2004.

S. Suriasumantri, Jujun. Ilmu dalam Perspektif: Sebuah Kumpulan Karangan Tentang Hakikat Ilmu, Jakarta: Yayasan Obor Indonesia, 1997.

Schimmel, Annemarie. Dimensi Mistik Dalam Islam, terj. Sapardi Joko Damono, Jakarta: Pustaka Firdaus, 2009.

Shihab, Alwi. Akar Tasawuf di Indonesia, Antara Tasawuf Sunni dan Tasawuf Falsafi, Bandung: IIMaN, 2009.

Sumedi, Kritisme Hikmah ke Arah Epistemologi Pendidikan Islam Humanis, Sinartikel Epistemologi Barat dan Islam, Yogyakarta: UIN Sunan Kalijaga, 2008.

Supadjar, Damardjati. "Sosok dan Perspektif Filsafat Islam Tinjauan Aksiologis", dalam Irma Fatimah (ed.), Filsafat Islam Kajian Ontologis, Epistemologis, Aksiologis, Historis, Perspektif, Yogyakarta: LESFI, 1992.

Supadjar, Damardjati. Filsafat Sosial, Serat Sastra Gending, Fajar Pustaka Baru, Yogyakarta. 2001.

Syukur, Amin dan Masharudin, Intelektualisme Tasawuf, Yogyakarta: Pustaka Pelajar, 2002.

Syukur, Amin. Tasawuf dan Kritis, Yogyakarta: Pustak Pelajar, 2001. 
Tafsir, Ahmad. Filsafat Ilmu: Mengurai Ontologi, Epistemologi, dan Aksiologi, Bandung: Rosdakarya, 2012.

Zainul Hamdi, Ahmad. Tujuh Filsuf Muslim, Pembuka Pintu Gerbang Filsafat Barat Modern, Yogyakarta: Lkis, 2004. 